\title{
Ecotoxicogenomic Approaches for Understanding Molecular Mechanisms of Environmental Chemical Toxicity Using Aquatic Invertebrate, Daphnia Model Organism
}

\section{Hyo Jeong Kim ${ }^{1,2, \dagger}$, Preeyaporn Koedrith ${ }^{1,3, \dagger}$ and Young Rok Seo ${ }^{1,2, *}$}

1 Institute of Environmental Medicine for Green Chemistry, Dongguk University Biomedi Campus 32, Dongguk-ro, Ilsandong-gu, Goyang-si, Gyeonggi-do 410-820, Korea;

E-Mails: hd414@naver.com (H.J.K.); pkoedrith@gmail.com (P.K.)

2 Department of Life Science, Dongguk University Biomedi Campus 32, Dongguk-ro, Ilsandong-gu, Goyang-si, Gyeonggi-do 410-820, Korea

3 Faculty of Environment and Resource Studies, Mahidol University, 999 Phuttamonthon 4 Rd., Phuttamonthon District, Nakhon Pathom 73170, Thailand

$\dagger$ These authors contributed equally to this work.

* Author to whom correspondence should be addressed; E-Mail: seoyr@dongguk.edu; Tel.: +82-31-961-5172.

Academic Editor: Ji-Dong Gu

Received: 31 March 2015 / Accepted: 15 May 2015 / Published: 29 May 2015

\begin{abstract}
Due to the rapid advent in genomics technologies and attention to ecological risk assessment, the term "ecotoxicogenomics" has recently emerged to describe integration of omics studies (i.e., transcriptomics, proteomics, metabolomics, and epigenomics) into ecotoxicological fields. Ecotoxicogenomics is defined as study of an entire set of genes or proteins expression in ecological organisms to provide insight on environmental toxicity, offering benefit in ecological risk assessment. Indeed, Daphnia is a model species to study aquatic environmental toxicity designated in the Organization for Economic Co-operation and Development's toxicity test guideline and to investigate expression patterns using ecotoxicology-oriented genomics tools. Our main purpose is to demonstrate the potential utility of gene expression profiling in ecotoxicology by identifying novel biomarkers and relevant modes of toxicity in Daphnia magna. These approaches enable us to address adverse phenotypic outcomes linked to particular gene function(s) and mechanistic understanding of aquatic ecotoxicology as well as exploration of useful biomarkers.
\end{abstract}


Furthermore, key challenges that currently face aquatic ecotoxicology (e.g., predicting toxicant responses among a broad spectrum of phytogenetic groups, predicting impact of temporal exposure on toxicant responses) necessitate the parallel use of other model organisms, both aquatic and terrestrial. By investigating gene expression profiling in an environmentally important organism, this provides viable support for the utility of ecotoxicogenomics.

Keywords: water flea; Daphnia spp.; ecological risk assessment; ecotoxicogenomics; predictive toxicology

\section{Introduction}

Recently, the term "ecotoxicogenomics" has been introduced [1-5] to describe the toxicogenomic context into ecotoxicological field (Figure 1) [6]. The toxicogenomic approach with the use of Daphnia magna as an aquatic invertebrate model advances our knowledge and understanding of ecotoxicity because current mechanism of chemical toxicity in invertebrates as well as potential biomarkers still need to be determined.

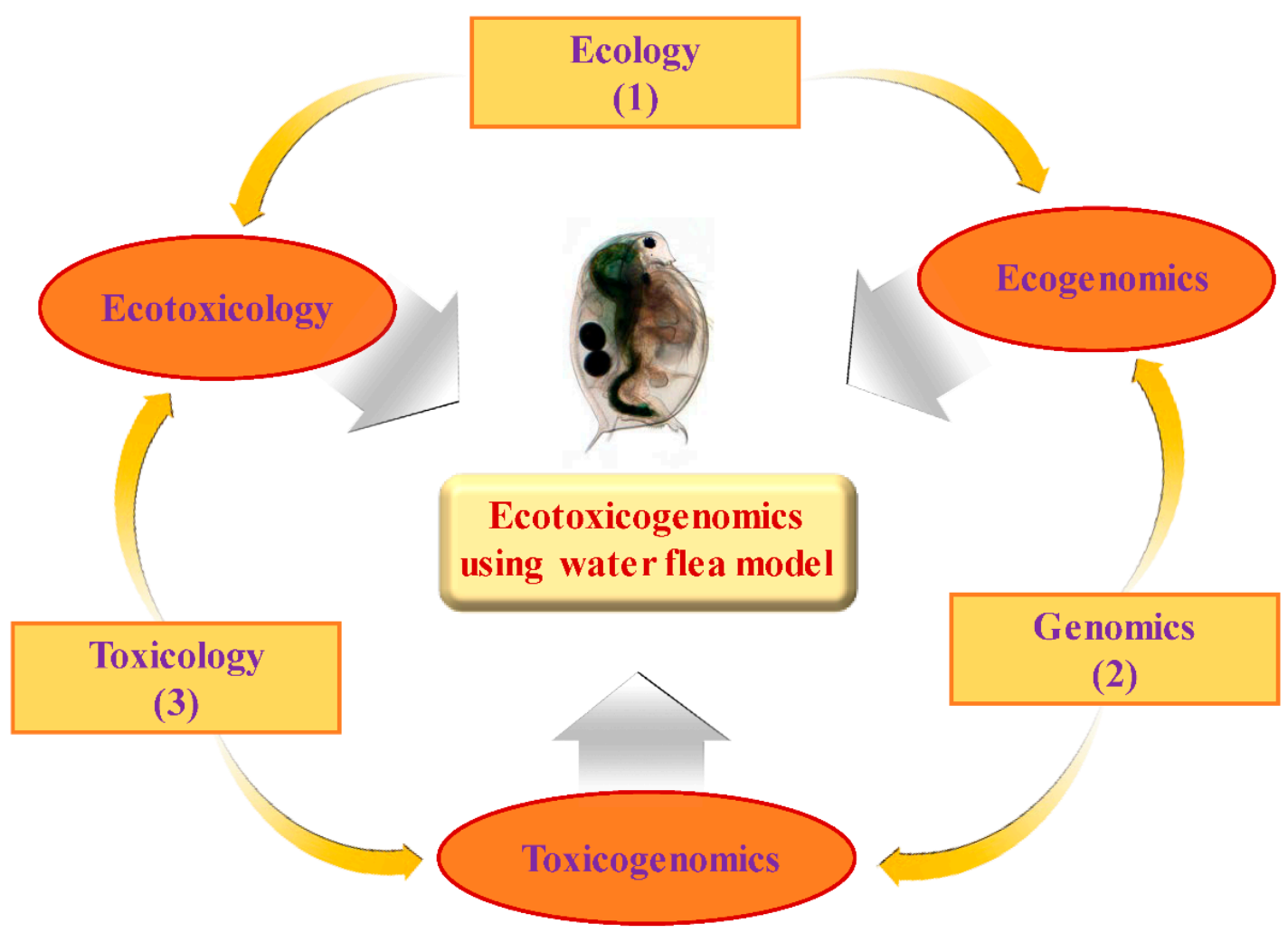

Figure 1. A scheme illustrating conceptual ecotoxicogenomics using Daphnia model. The thin arrows connect primary fields of study (in rectangles) to form interdisciplinary fields (in circles). The thick arrows indicate the tools or the knowledge that can be applied to integrated multidisplinary data sets, for instance: (1) ecological surveys; (2) genomic tools; (3) toxicity tests. 
Basically, environmental pollutants may alter genomic expression profiles in an organism. In biomedicine, gene expression pattern is altered, directly or indirectly, owing to toxicant exposure in most cases [7]. Depending on the extent and period of the toxicant exposure, genomic alterations may be transient toxicological responses resulting in changes of "fitness" (survival and reproduction), or the "genotoxic disease syndrome" [8]. Previous studies have shown genotype-dependent effects in animals experienced to toxicants [9-11].

Daphnia is a keystone aquatic organism in the pelagic zone of most fresh water habitats (ranging from arctic and temperate lakes, lakes at high elevations, ephemeral ponds, to ponds in sand-dunes) and offers a key relationship between primary producer and higher trophic levels [12,13]. The establishment of ecology, phylogeny, toxicology, and physiology in Daphnia as well as its genome sequence accessibility (wfleabase.org) allow the development of genetic tools, such as genetic linkage map, [14], cDNA libraries and microarrays [6], and consequently investigate environmental impacts on gene functions in other model organisms that are difficult to be studied $[15,16]$. In particular, the availability of genetic linkage maps and the transferability of crossing panels across laboratories can facilitate the diagnosis of potential ecological and environmental traits via quantitative trait locus (QTL) analysis as well as the identification of heritable genotype-associated gene expression with the use of eQTL (expression QTL) approaches.

Among freshwater organisms, daphnids have relatively high sensitivity to environmental contaminants [17]. Upon exposure to environmental stressors, daphnids exhibit significant reproductive decline [18], aberrant vertical mobility and behavioral pattern, and ultimately phenoplasticity [19-22]. These abiotic and biotic stressors in common include chemical substances, synthetic hormones, acidity, salinity, calcium levels, hypoxia, radiation, bacterial pathogens, predators and parasites [16]. Among Daphnia's closely related species, their multiple habitat transitions may be attributable to the extremely "eco-responsive genome" [16,23]. Among Daphnia closely related species complexes including Daphnia galeatamendotae, Daphnia longispina, and Daphnia pulex, their ecologically relevant traits are likely associated with the colonizing habitats under distinct environmental conditions [24-26]. The multiple lineages independently colonized and adapted to these freshwater habitats are distinguished in terms of extent of reproductive isolation and intraspecific genetic subdivision among populations $[27,28]$.

In the field of molecular biology at post-genomic era, the availability of DNA sequence data combined with advent in genomic tools and technologies will promote the direct interrogation of gene expression at multiple levels in organisms experienced to various environmental stressors. Given that the genome sequencing tool has the potential to identify an increased number of ecologically relevant species in both vertebrates and invertebrates, this holds great promise to address the phenotypic and genotypic linkage based on fitness using a "bottom-up" approach from molecular to ecosystem level (Figure 2) [2]. 


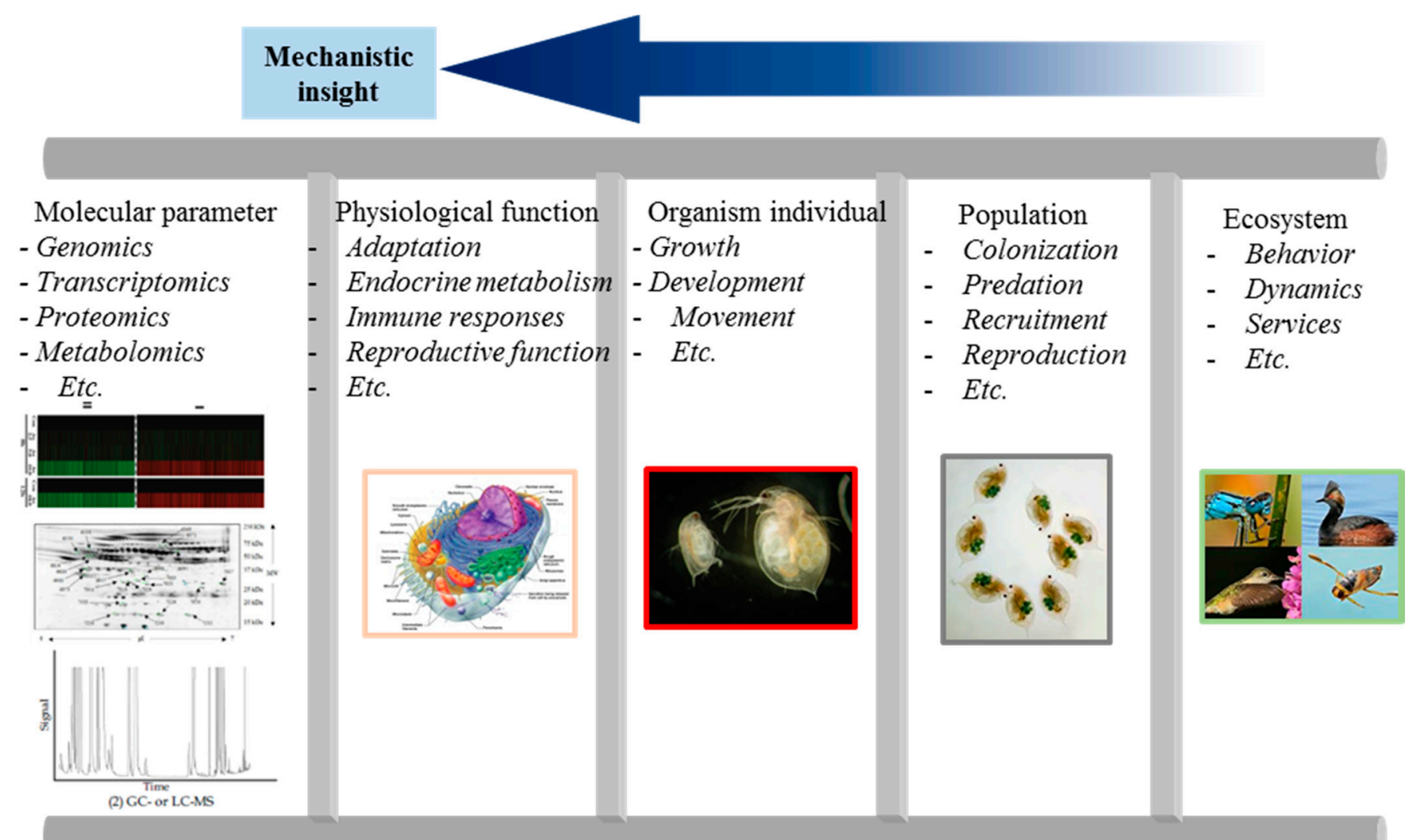

Ecological

insight

Figure 2. A scheme representing multilevel-framework for ecotoxicogenomic studies at multiple levels ranging from molecular, physiological, organismal, and population in ecosystem.

Genomic tools can facilitate ecology and evolutionary biology studies, allowing advance fundamental information and addressing the future issues related to chemical effects on environmental and human health. Purpose of this framework include: identification of ecological performance-regulated gene loci; functional analysis of ecological performance-related traits; evaluating individual, population, community, and ecosystem responses to the environment; examining the degree and significance of genetic variation among ecological performance-related traits [2].

Of ecological significance, omics technologies including microarrays enable rapid quantification of molecular variation among populations at multiple gene loci [2]. In the UK, the Natural Environment Research Council (NERC) Environmental Genomics Programme has been established in order to: examine the consequence of genetic variation on ecological performance; determine the degree of spatial and temporal variation at regulatory versus structural loci; investigate numbers of loci and their genomic distribution; and assess community structure and the influence of environmental alteration. At environmental contaminated sites, the omic tools are also useful for investigating important issues as follows: what are inducible genes and their functions; is there variation in gene expression in response to environmental change; is the variation adaptive; what are the consequences of the genetic variation-mediated molecular transformations at ecosystem-, community-, and population-level. 
The omics-based technologies can facilitate comprehensive investigation to better understanding and improve the knowledge on how environmental stressors, such as heavy metals and persistent organic pollutants, cause toxicity in ecologically relevant organisms and adverse effects in ecosystem [29]. In this review, we mainly discuss three aspects: the commonly used omic technologies, including genomic (or mRNA-transcriptomic), proteomic, metabolomic analyses, and more recently emerged epigenetic technology; collective technologies (i.e., cDNA microarray, high-density oligonucleotide arrays, suppression subtractive hybridization PCR or high-throughput pyrosequencing, two-dimensional gel electrophoresis, fluorescence difference gel electrophoresis, ProteinChip, surface-enhanced laser desorption ionization (SELDI) mass spectrometry, and nuclear magnetic resonance) in conjunction with statistical testing or multivariate analysis; as well as development of bioinformatics tools and their application to aquatic ecotoxicology studies.

\subsection{Practice of Ecotoxicogenomics in Genomic or Transcriptomic Responses}

The DNA microarrays applied to ecotoxicology have ranged from nylon membranes that are custom spotted with a couple dozen selected cDNAs [30-32] to commercially available, high-density arrays consisting of thousands of oligonucleotides synthesized directly onto a solid support such as a glass slide [33-35]. To date, the availability of commercial, high-density oligonucleotide microarrays has been largely restricted to prominent model organisms for which considerable sequence information is available, such as zebrafish (Danio rerio), frog (Xenopus larvis), and fathead minnow (Pimphales promelas). Although the genomes of other species have not been completely sequenced, DNA microarrays have been developed and applied for studying a variety of additional model organisms for ecotoxicity testing. Coordinated efforts to share sequence information and other resources, such as the Daphnia Genomics Consortium (http://www.daphnia.cgh.indianna.edu/) and the Consortium for Genomic Research on All Salmon (http://www.web.uvic.ac/grasp/), have greatly assisted the development of genomic tools for other model organisms. Up-to-date, high density customized microarrays of cDNA- or oligonucleotide-based chips containing thousands of targets have been dominantly developed for global analysis of transcripts associated with exposure to chemical or environmental stressors in ecotoxicology studies.

The emergence of transcriptomics as a tool for ecosystem characterization is perhaps best shown by the fact that transcriptomics has been applied to a diverse group of species and stressors, representative of those traditionally examined in context of ecological risk assessment [29]. As a common test organism, the aquatic invertebrate, D. magna has also been used in a number of ecotoxicology-oriented transcriptomics studies [36-39]. To date, Daphnia and fish, particularly zebrafish and fathead minnow, appear to be the most common model organisms for ecotoxicogenomics studies employing DNA microarrays. As DNA sequencing technology becomes increasingly rapid and cost effective, the available sequence information for diverse taxa continues to grow, making it increasingly feasible to apply transcriptomic approaches to nearly any species of concern [40].

For example, the first version cDNA microarray of D. magna based on Suppression Subtractive Hybridisation PCR (SSH-PCR) 855 life stage-specific cDNAs has been successfully applied for elucidating mode of toxicity of propiconazole pesticide [41]. After 4 days of exposure to $1 \mu \mathrm{g} / \mathrm{mL}$ propiconazole, vitellogenin gene was repressed, suggesting that oocyte maturation was affected. The 
vitellogenin mRNA might be considered as an early warning biomarker of chronic reproductive effects in aquatic invertebrates. Metal toxicity study was performed using a customized Daphnia magna cDNA microarray toward sublethal exposure to cadmium, copper, and zinc [37]. This finding revealed that distinct expression patterns toward each metal, and plausible exposure biomarkers, including putative metallothioneins and ferritin mRNA with a functional IRE were identified. Furthermore, using systems biology approach, transcriptomic patterns and phenotypic features were analyzed in D. magna model following exposure to ibuprofen, a nonsteroidal anti-inflammatory drug [36]. Result indicated that ibuprofen would affect reproductive capability at molecular-, organism-, and population-level in daphnids. Microarray data demonstrated ibuprofen-mediated early disturbance in crustacean eicosanoid metabolism via signal transduction, resulting in aberrant juvenile hormone metabolism and oogenesis. Recently, microarray analysis in combination with reproduction testing assay was conducted in D. magna system in order to determine bisphenol-A(BPA) toxicity since BPA has detrimental health impacts, particularly in reproduction, development, and organismal behavior [42]. Microarray results revealed significant change in expression levels of candidate genes homologous to animal nucleotide sequences, including cuticular protein, vitellogenin, protease, and ribosomal proteins. These genes reportedly discovered in other animal models might be recognized as novel biomarkers indicative of BPA exposure $[42,43]$. The application of genomic techniques into environmental toxicology holds great promise to identify exposure biomarkers and clarify the mode of toxicity of newly synthesized chemicals [44]. Using 15k oligonucleotide microarray, D. magna was also used as an aquatic model to investigate nanotoxicity, specific biomarkers, and effects of coating agents; for instance, citrate-coated and polyvinylpyrrolidone (PVP)-coated silver nanoparticles (AgNPs) in comparison to bulk silver nitrate $\left(\mathrm{AgNO}_{3}\right)$ [44]. The microarray data showed distinct expression patterns toward $\mathrm{AgNPs}$ and $\mathrm{AgNO}_{3}$, indicating distinct modes of toxicity. AgNPs affected to biological processes, especially protein metabolism and signal transduction whereas $\mathrm{AgNO}_{3}$ suppressed sensory developmental processes. Only PVP-coated AgNPs could upregulate metal-and DNA repair-related genes. PVP-coated AgNPs-specific biomarkers, including metallothionein (MT) and DNA damage repair (REV1) gene might be useful for the environmental detection.

Regardless of the stressor(s) examined, the most prominent use of transcriptomics has improved the understanding of the mechanisms of action through which various stressors elicit or modulate adverse effects [29]. Mechanistic ecotoxicogenomic studies rely heavily on genome annotation to identify the specific transcripts modulated by exposure to a particular stressor and gain an understanding of the biological functions and pathways represented by the differentially expressed genes. Qualitative and quantitative analysis of "enriched" gene ontology (GO) terms tends to be one of the central analytical approaches used in mechanistic studies. Application of automated pathway analysis tools has been somewhat limited by the lack of standardized pathways for ecological model species (i.e., non-human, non-rodent). However, pathway-oriented analyses can still be conducted by hand $[45,46]$ or by using bioinformatics approaches to identify human or rodent homologs and applying pathway tools developed for those species [40,47]. Ultimately most mechanistic transcriptomic studies have had to rely heavily on information available in the extant literature to make sense of the numerous, and often disparate, responses that are observed following exposure to a stressor.

Transcriptomic studies have already produced a greater appreciation of the concept that exposure to stressors, even those traditionally thought to act through specific pathways, impacts on many 
fundamental cellular processes such as energy metabolism, protein metabolism, cell cycle, cytoskeletal organization, immune/inflammatory processes, and extracellular matrix development [34,48,49]. Microarray studies suggest that extensive crosstalk among pathways is perhaps the rule, more than the exception. Given the global nature of microarray analysis, one of the key challenges of mechanistic studies is differentiation of general stress responses from responses that are specific to a given mode or mechanism of action [50-52]. Furthermore, transcriptomic research appears to be enhancing appreciation for adaptive or compensatory responses to stressors as well $[45,53,54]$. The ability to differentiate adaptive responses from adverse ones is critical if transcriptomic responses are to be used as a basis for predictive ecological risk assessment.

Toxicogenomics researchers have clearly recognized the need for phenotypic anchoring to link changes at the molecular level to outcomes at higher levels of organization. The majority of mechanistically oriented transcriptomic studies in ecotoxicology have included a variety of apical endpoints. For example, transcriptomic results for Daphnia magna were anchored to embryo abnormalities and carapax length in one study [55] and population growth rates in another [39]. An ecotoxicogenomic assessment of D. magna with the use of expressed sequence tags (ESTs) and the database has been conducted [56]. Based on this sequence information, an oligonucleotide-based DNA microarray has been developed in order to determine the acute toxicogenomic profiling of D. magna in response to various types of chemical stressors, including copper sulfate $\left(\mathrm{CuSO}_{4}\right)$, hydrogen peroxide $\left(\mathrm{H}_{2} \mathrm{O}_{2}\right)$, pentachlorophenol (PCP), and $\beta$-naphthoflavone ( $\beta \mathrm{NF}$ ) as testing substances exerting distinct toxicities. The result showed that neonatal daphnids exposed to these compounds have distinct transcriptional changes toward each chemical. However, it is necessary to relate molecular mechanisms to toxicological outcomes when mechanistic ecotoxicogenomic studies in aspect of "proof-of-concept" are conducted.

While ecotoxicogenomic studies have tended to focus on mechanisms, mechanistic research has not been conducted to the exclusion of fingerprinting approaches and biomarker discovery (Figure 3) [2]. Many in the field have used their transcriptomic data to both explore mechanisms and attempt to identify transcriptional fingerprints or biomarkers potentially indicative of specific types of exposure or effects. For example, Poynton et al. [37] identified distinct expression profiles in Daphnia magna for three different metals, found support for known mechanisms of metal toxicity, and postulated inhibition of chitinase activity by zinc as a novel mode of action [37].

Alternatively, techniques for high-throughput transcription analysis that are not relied on a priori information of DNA sequence database include suppression subtractive hybridization PCR and high-throughput pyrosequencing [57]. Nevertheless, the data interpretation somewhat depends on the knowledge of genome like that in microarray techniques. Several setbacks of the microarray techniques may thus be employed to the aforementioned techniques.

This notwithstanding, researchers can predict that, except for genome model species, only a 5\%-10\% of the genome can be related to known genes and thus to defined functions. New functional data, novel developments in bioinformatics, and completion of sequencing projects will be needed to conciliate the spectrum of species and taxa required for an in depth analysis of environmental impacts, and the limitations of transcriptomic and functional analyses.

Even in laboratory model organisms, much effort is still needed for gene functional analysis. In the genetic organism models (e.g., Saccharomyces cerevisiae, Caenorhabditis elegans, Drosophila, and Mus musculus), gene functions can be analyzed on the phenotypic characterization of mutants, 
transgenic organisms using common techniques (i.e., knockdown or gene silencing, knockouts, and the reverse genetics method [58]. Some of these conventional genetics methods become available in D. magna [59,60], ecotoxicogenomics-based approaches would be complementary with the validation of results obtained by those techniques. Ecotoxicogenomics-oriented research in such small organisms like the water flea may help to overcome the difficulties in the higher levels of ecological organisms in terms of studying the whole organism.

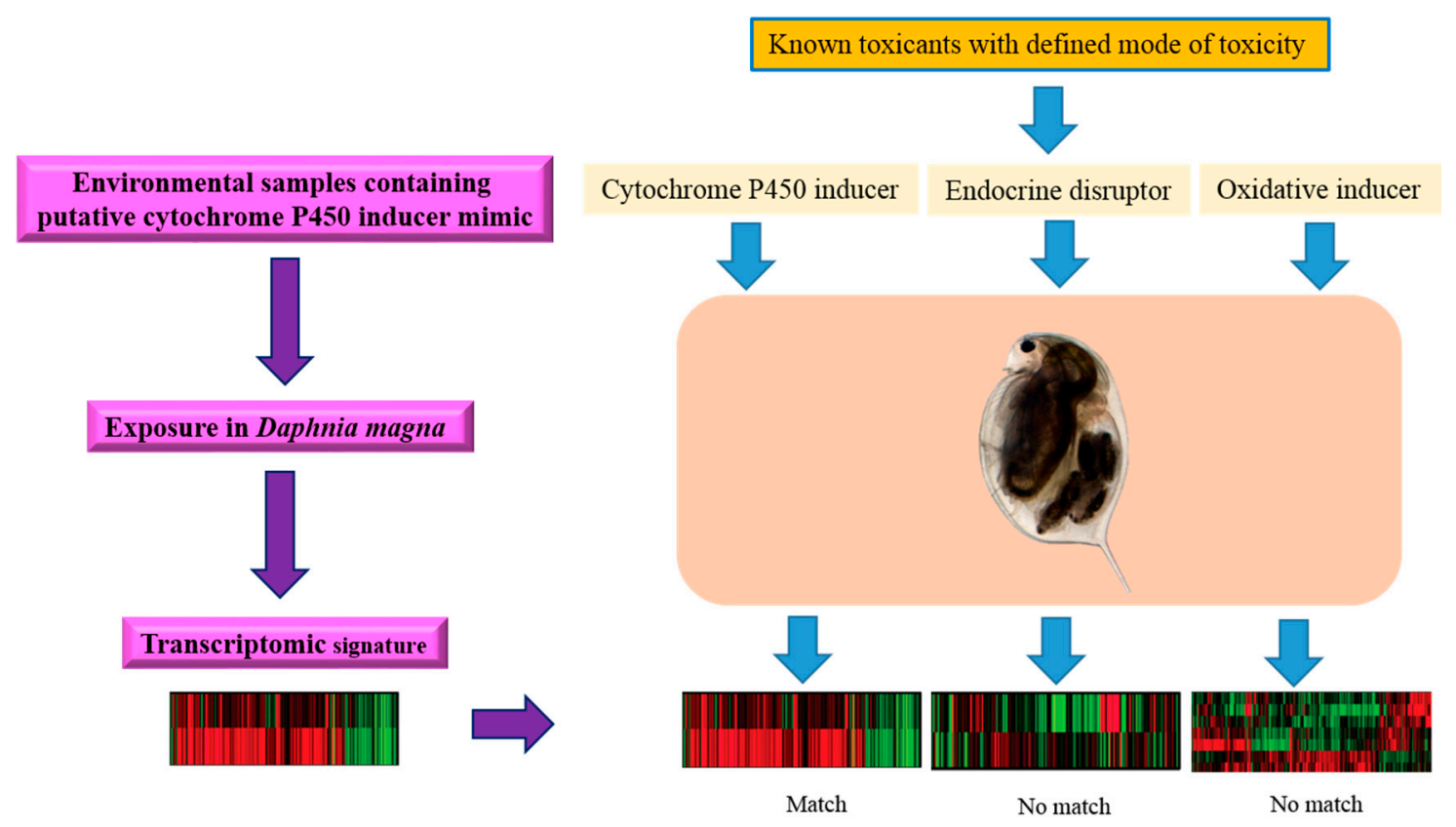

Figure 3. A scheme illustrating the utility of gene expression signatures to explore the possible mode of toxicity of an unknown environmental toxicant in an aquatic model organism (Daphnia spp.).

\subsection{Practice of Ecotoxicogenomics in Proteomic Response}

To date, proteomics has been the second most widely used of the omics approaches applied to ecosystem assessment [40]. Proteomic studies account for around 10\% to $15 \%$ of published ecotoxicology-oriented "omics" research. Most of the proteomics studies have focused on fish and mussels.

In contrast to transcriptomics-based ecotoxicology studies, which, to date, tend toward mechanistic investigation, proteomics-based ecotoxicology has skewed heavily toward identification of fingerprints, most often referred to as protein expression signatures (PES). There are two dominant practical approaches to PES generation. ProteinChip technology along with SELDI mass spectrometry, also known generally as retentate chromatography-mass spectrometry (RC-MS) [61], is the most common analytical technique used for PES identification. The second most prominent is two-dimensional gel electrophoresis and matrix-assisted laser deionization (MALDI)-based mass spectrometry has also been employed.

Laboratory-based proof-of-principle type studies aimed at PES identification have shown some promise. Early on, this primarily consisted of work that employed two-dimensional gel electrophoresis (2-DE) and showed that exposure to different chemical treatments resulted in distinct spotting patterns on the gels [62-64]. While these studies provided basic support for the hypothesis that exposure to a 
given stressor would yield a unique profile of protein expression, limitations associated with the technical reproducibility of 2-DE were a significant barrier to wide applications of the technique for environmental, or even laboratory, diagnostic applications [65]. The second generation of proteomics studies aimed at identification of PES has made greater use of more sensitive and reproducible technologies, for example, using SELDI time-of-flight (TOF) mass spectrometry (MS) (SELD-TOF MS), fluorescence difference electrophoresis (DIGE) and MS, SELD-TOF MS with a weak cation exchange ProteinChip, and either SELDI-TOF MS or MALDI-TOF MS in conjunction with ProteinChip arrays. At present, the bulk of published evidence suggests that, at least under controlled laboratory conditions, exposures to various types of stressors can be discriminated based on proteomic profiles in a variety of sample types.

While laboratory-based discrimination of stressors may have utility for prospective assessments, diagnostic assessment requires methods that can be applied to samples collected from less controlled field conditions [40]. A number of studies have investigated the applicability of proteomic approaches to field-based assessments, for example, using SELDI-TOF MS and a ProteinChip with a strong anionic exchange surface. To date, the evidence collected broadly supports the notion that PES can be used to discriminate among sites with differing stressor profiles.

The current body of work establishes an effective proof of principle, that is, stressors elicit changes in the proteome that can be detected and used as a basis for class discrimination [40]. It remains to be seen whether the discriminatory capabilities of proteome fingerprinting, demonstrated in the laboratory and field, will ultimately be useful for risk assessment. To date, we are not aware of any studies that have examined whether specific PES or proteomics-based class separation models identified through statistical testing or multivariate analysis, such as principal components analysis (PCA), partial least squares discriminant analysis (PLS-DA), and neural networks can be consistently reproduced and successfully applied in multiple independent laboratory or field studies. Few proteomics-based ecotoxicology studies have examined the degree to which PES vary as a function of either time or stressor concentration/severity. Additionally, the influence of confounding environmental variables such as temperature, habitat quality, diet, predator/prey, or host/parasite relationships have not been examined.

Researchers in the field of environmental proteomics are aware of the ongoing need to generate greater confidence in the accuracy, reproducibility, sensitivity, and robustness of the methods before they are integrated into risk assessments [66]. As such, the ongoing challenge relative to application of PES in ecological risk assessment is not only identifying proteomics-based classification models that can discriminate among various groups of samples, but evaluating and establishing the specificity and robustness of those models across widely varying experimental or environmental conditions are also of concern.

For example, using the two-dimensional gel electrophoresis (2-DE) technology impacts of toxic heavy metals such as $\mathrm{As}(\mathrm{III}), \mathrm{As}(\mathrm{V})$ and $\mathrm{Cd}$ and their binary mixtures on proteomic profiling in D. magna were assessed in order to explore novel protein biomarkers [67]. The result demonstrated that 117 totally altered proteins might be recognized as plausible protein biomarkers in D. magna for sensing heavy metals in the aquatic ecosystem. It also suggested that binary mixtures of heavy metals in D. magna present somehow molecular interactive complexity, rather than simple sum of the proteomic profiles of the individual metals. Using a redox-focused proteomic approach by labeling protein carbonyls with fluorescein-5-thiosemicarbazide (FTC) prior to 2-DE, proteomic profiling and molecular 
biomarkers were successfully evaluated; meanwhile whole organism-based toxicity and biochemical testing were analyzed in D. magna exposed to citrate-coated silver nanoparticles (AgNPs) compared to bulk silver nitrate $\left(\mathrm{AgNO}_{3}\right)$ [68,69]. Levels of vitellogenins were increased upon exposure to both compounds, suggesting their functionally overlapped general stress response. Hemoglobin levels were increased toward AgNP exposure whereas 14-3-3 protein (a regulatory protein) carbonylation levels were decreased upon $\mathrm{AgNO}_{3}$ exposure, indicating that both silver compounds has distinct impact on biological pathways possibly resulting in differential interactions with either natural or xenobiotic substances in the aquatic environment.

\subsection{Practice of Ecotoxicogenomics in Metabolomic Response}

Among the "omics" approaches, metabolomics has been the least widely applied to ecotoxicology [40]. Whereas transcriptomics and proteomics attempt to examine the entire complement of transcripts or proteins, respectively in a sample, metabolomics is concerned with the complement of small molecule metabolites found in biological samples [40]. Metabolomics studies account for approximately 5\% of published ecotoxicogenomic studies. The majority of these have employed nuclear magnetic resonance (NMR) spectroscopy as the primary analytical technology. However, mass spectrometry (MS)-based environmental metabolomics studies are beginning to appear in the literature as well [70-72].

Similar to proteomics, the majority of ecometabolomics studies have focused on demonstrating that distinct metabolic profiles are observed for organisms exposed to different types of chemical stressors either in the laboratory or in the field [40]. Multivariate pattern-recognition analyses are typically used to assess complex differences between spectra. Thus, studies with a variety of species and stressors have demonstrated the ability to discriminate among groups using metabolite profiles, and to identify specific metabolites that may serve as biomarkers. However, to date, we are not aware of any concerted efforts to develop libraries of "metabolic fingerprints" for use in identifying or classifying various types of exposures or effects.

When specific metabolites that were altered by a chemical exposure or differed among populations exposed from different (contaminated) environments can be identified, metabolomics studies also have the potential to yield mechanistic information [40]. Cautions have been raised that ad hoc attempts to infer mechanisms, based on metabolomic data in isolation, are not likely to be successful [73].

For example, an effective approach of high throughput, ultrahigh resolution mass spectrometry based metabolomics namely "direct infusion Fourier transform ion cyclotron resonance mass spectrometry (DI FT-ICR MS)" has been established as an exceptional tool in D. magna [74]. Copper was used as a testing chemical to validate this technique with an OECD $24 \mathrm{~h}$ acute toxicity testing in both univariate and multivariate models in order to screen and prioritize chemicals within tiered risk assessment. Later work with use of FT-ICR MS based metabolomic approach was successfully validated with $D$. magna toxicity testing to evaluate the acute metabolomic effects of chemicals and their mode of toxicity [75]. Test compounds with distinct toxicity modes including cadmium (oxidative stress inducer) [76], fenvalerate (sodium channel activator) [77], 2,4-dinitrophenol (DNP) [78], and propranolol (nonselective $\beta$-blocker) [79] were employed to evaluate whole-body metabolome relative to hemolymph metabolome with use of supervised multivariate modeling. The finding indicated that metabolomic patterns derived from whole-daphnids have discriminatory accountability to MOA of 
chemicals rather than hemolymphs as well as early metabolomic responses enable reflect discriminatory acute toxicities of chemicals. Furthermore, the integration of hemolymph metabolomics namely "FT ICR MS and NMR spectroscopy" and whole-daphnid transcriptomics namely "D. magna 44k oligonucleotide microarray" based method in conjugation with use of KEGG pathway database and gene ontology offers holistic insight on how cadmium at sublethal concentrations for $24 \mathrm{~h}$ interrupt nutrient uptake and metabolism. This thus led to impaired energy production, resulting in chronic toxicity [80].

Recently, ${ }^{1} \mathrm{H}$ NMR-based metabolomics has been applied as viable platform for investigating metabolomic profiling and mode of toxicity of $D$. magna upon exposure to toxic metals including arsenic, copper, and lithium at sublethal concentrations for $48 \mathrm{~h}$ [81]. Metabolomic responses under all treatments were statistically compared using principal component analysis (PCA), and differentially expressed metabolites were quantitatively identified. Metabolomic data indicated that lithium exposure significantly exhibits an analogous mode of toxicity to copper as evident by disrupted energy reservoir and regulation, while arsenic exposure has a metabolic shift with non-significant changes.

\subsection{Practice of Ecotoxicogenomics in Epigenetic Response}

Epigenetic effects can be defined as inheritable changes in phenotypes, by either mitotically or meiotically, without changes in DNA sequence [82]. Gene expression changes can be mediated via well-studied processes including DNA methylation, histone modifications, and RNA interference as well as less well-studied epigenetic processes (i.e., histone variation, nucleosome phasing, higher-order chromatin structure organization, and nuclear localization [83,84].

DNA methylation, which is occurred by either de novo or maintenance DNA methyltransferases, is related with transcriptional regulation, chromosome inactivation, and transposable element regulation [85]. Even though DNA methylation is present in various eukaryotic organisms, the degree of methylation and the chromatin structure organization are dependent on species and developmental stages [83]. DNA methylation interacts with other epigenetic processes including histone modifications at amino- or carboxyl-termini, thereby affecting chromosome coiling and accessibility to transcriptional machinery and ultimately resulting in gene expression changes [86,87]. Additionally, DNA methylation and histone modifications can interact with the RNA interference (RNAi) system that is involved in the generation of small noncoding RNA molecules (ncRNA) [88]. The nc RNAs, such as microRNA (miRNA) and short interfering RNA (siRNA) can form RNA-induced silencing complexes (RISC) that recruit DNA methyltransferases and histone modifying enzymes [89].

Epigenetic markers are regulated by environmental conditions (i.e., nutrients, chemical stressors, hypoxia, and developmental stages) [90]. For example, histone methylation status can be modified by hypoxia via interruption of Jumonji protein (JMJD2) activity in aquatic system [91]. Indeed, the term "epigenetics" can be simply described to any environmentally modified process of DNA, such as DNA methylation or histone modification regardless to maternal inheritability. For example, previous studies revealed that transgenerational incidence is unlikely related to methylation status in either Daphnia [92] or Fundulus [93].

These epigenetic mechanisms in normal Daphnia development and their adaptations remain to be elucidated. Vandegehuchte et al. [94] have firstly discovered that D. magna is capable of methylating DNA as well as genes homologous to major vertebrate DNA methyltransferases (Dnmt1, Dnmt2, and 
Dnmt3A) with their activities confirmed [94,95]. Using ultra-performance liquid chromatography (UPLC) and microarrays, DNA methylation and transcriptome profiling were respectively analyzed in D. magna exposed to several chemicals [96]. This finding showed that global or localized DNA methylation levels could be altered by 5 -azacytidine, vinclozolin, genistein, and zinc but not by 5aza-2'-deoxycytidine, biochanin A, and cadmium [94,96]. The transgenerational impacts of methylation status were also determined [96].

With available accessibility of complete genome for D. pulex and D. magna, the advanced techniques, such as bisulfite sequencing, methylated DNA immunoprecipitation (meDip), or DNA methylation sensitive restriction enzyme digests preferably enable measurement of methylation status of particular genes, offering biologically meaningful information. Using these methods, D. magna's certain genes related to growth and reproduction were definitely determined since body length, brood size and sex determination as well as helmet and neck-teeth are affected upon exposure to toxicant [92,94,96-100].

Regarding to Daphnia epigenetics in DNA methylation process, $\mathrm{CpG}$ methylation is occurred at relatively low level but it is sensitive to developmental stage, as evident by the 2-fold increase in percentage of $\mathrm{CpG}$ dinucleotides in adults at 32-day age compared to that at 7-day age [101]. In epigenetic aspects in other core processes (i.e., histone modification or noncoding RNA), or the impact of these epigenetic mechanisms on either normal development or the well-known predator-induced epigenetic polyphenisms, this information is still lacking. For example, previous investigation reported that both histone $\mathrm{H} 3$ and $\mathrm{H} 4$ modifications were occurred in embryonic cells. Interestingly, histone $\mathrm{H} 3$ dimethylated at lysine 4 (H3K4me2) was non-uniformly present in a cell-cycle-specific manner in D. magna gastrula cells but was absent in oocytes.

\section{Suggestion of Promising Biomarkers of Environmental Toxicity or Exposure}

The toxicogenomic studies using Daphnia have potential advantages not only to identifying interlinked crosstalks and biological processes in response to environmental toxicants, but also to suggest promising biomarkers that are indicative of certain types of environmental stressor's effect or exposure. Indeed, this recognizes the need for phenotypic anchoring to link changes at the molecular level to outcomes at higher levels of organization. The majority of mechanistically oriented transcriptomic studies in ecotoxicology have included a variety of apical endpoints. In various studies about toxicity using Daphnia as an aquatic test model to metals, endocrine disruptors, drugs and so on, data enables us to understanding the symptoms induced by those toxicants. Although the detailed pathways and mechanisms of the toxic effects have not been clearly elucidated, Daphnia-customized microarray data, in particular, reveals a number of biomolecules including genes involved in ion transport and chelating (ferritin, putative metallothionein), metamorphosis (vitellogenin and chitinase), invertebrate immune system (eicosanoid), glycolytic and proteolytic process (amylase, cellulose, esterase, and serine protease), cellular anti-oxidative defense (glutathione- $S$-transferase, catalase, and peroxiredoxin), and stress response (heat shock proteins) that have been predominantly recognized as suggestive biomarkers in response to environmental stressor's exposure or effect (Figure 4) [37-39,102,103]. 


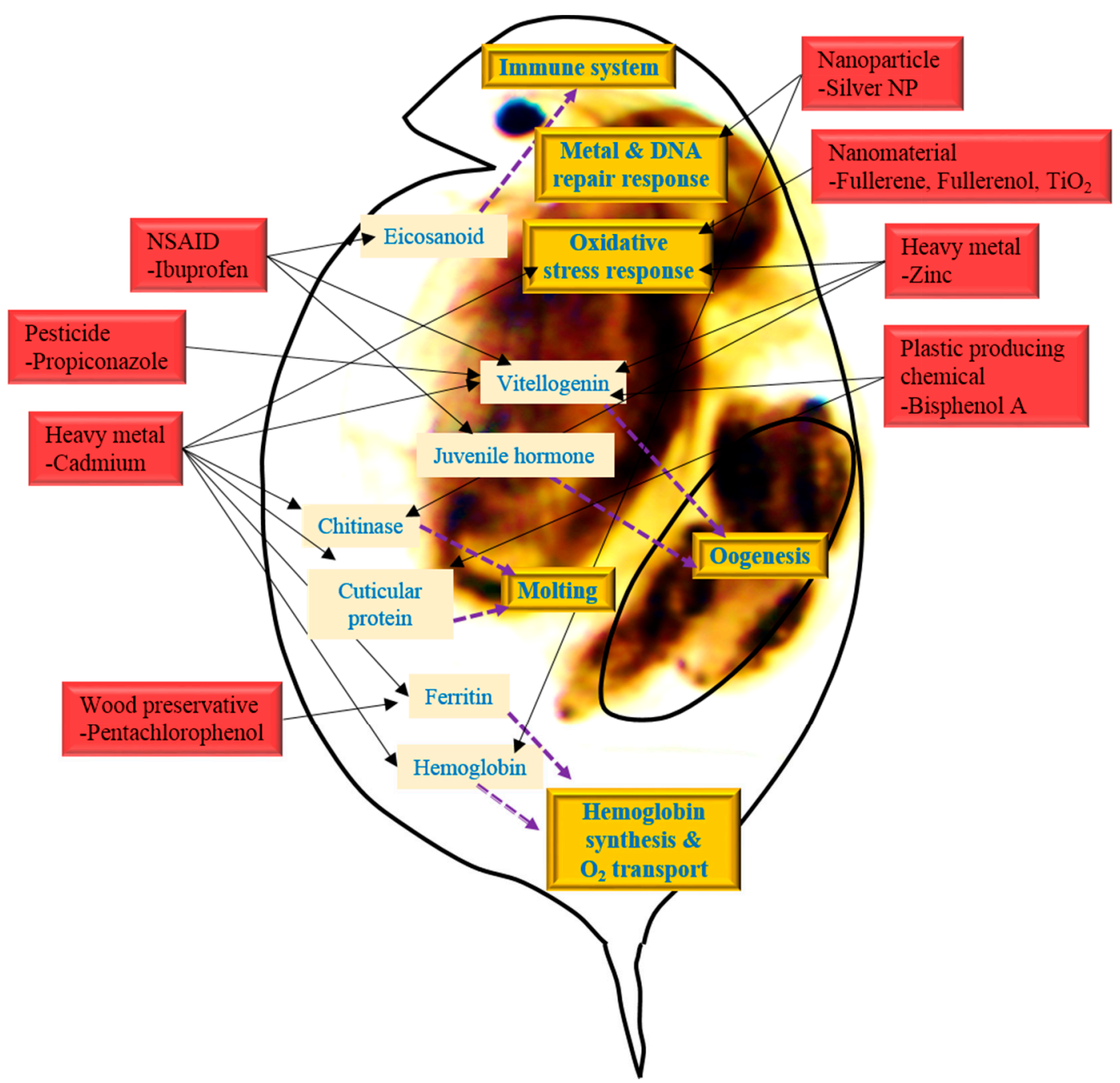

Figure 4. A scheme showing overview of biomarkers and biological interactions in Daphnia in response to stressors (as indicated 3-D red square). These candidate genes might be considered as potential biomarkers (as indicated in pink square), and their products are involved in important biological processes (as indicated in 3-D orange square) via interference with certain biomolecules (as indicated in 2-D pink square).

Heckmann et al. [104] revealed the profiles of critical genes in daphnia caused by ibuprofen exposure using microarray and temporal real-time quantitative PCR. In acute ibuprofen exposure, several genes, such as Lip (triacylglycerollipase), Ltb4dh (leukotriene B4 12-hydroxydehydrogenase), FABP3 (fatty acid binding protein 3), DmagVTG1 (vitellogenin 1), dmHb (hemoglobin), JHE (juvenile hormone esterase), VMO1 (vitelline outer layer membrane protein 1), and Cht (chitinase) are up- and down-regulated, inducing or suppressing the metabolisms and cellular processes. Lip and Ltb4dh are linked to eicosanoid metabolism and play a vital role in the invertebrate immune system, and FABP3 induce Peroxisome Proliferator Activated Receptor (PPAR) signaling pathway in the endocrine system. A temporal expressed gene, Cht is a key enzyme to molting fluid enzyme secreted during apolysis [105]. JHE, DmagVTG1 and VMO1 is related to oogenesis of daphnia, and separately expressed at different times in the developing oocyte [104].

Cadmium exposure microarray data are also analogous to ibuprofen exposure data, inducing glycolytic, proteolytic, homeostatistic, heat shock protein genes, and oxidative stress responses. Up-regulated Cht 
gene encoding chitinase and CYP450 gene encoding Cytochrome P450 monooxygenase, down-regulated LDLa encoding low-density lipoprotein receptor domain class A, and DD5 gene encoding a cuticular protein are involved in endocrine system of molting. In addition, up-regulated ferritin 1-like protein A and hemoglobin 2 (BJ9311841) and down-regulated hemoglobin1, 2 (BJ932805), 3 are linked to iron storage and iron absorption. Up-regulated ferritin genes in D. magna have previously been associated with cadmium exposure [37,102]. The general stress response gene HSP70 is also up-regulated [39].

The concentrations and time periods have an effect on different gene expression profiles. Soetaert et al. [102] stated that alteration of gene expression resulted from high concentration of cadmium. According to performed microarray data, 266 genes changed their expression after cadmium exposure. The genes are related to several cell processes including digestion, oxygen transport, vitellogenin, cuticular metabolism, immune response, acid-base balance, visual-sensory preption and signal transduction. The up-regulated genes, cellulase (DW724578), alpha-amylase (DW985556) and alpha-esterase (DW724473), induce digestive processes of carbohydrates and lipids. Hemoglobin (dhb1) (DW724693) and di-domain hemoglobin precursor were down-regulated, resulting in transport of less $\mathrm{O}_{2}$. Furthermore four genes encoding vitellogenin, two of which are well documented in Daphnia magna [vitellogenin1 (DY037262) and vitellogenin2 (DY037256)], were also down-regulated. Seven genes related to cuticula metabolism showed altered expression [102].

In the case of cadmium and copper exposure, D. magna ferritin gene (AJ292556) was up-regulated. Putative metallothionein1 (MT1) cDNAs, DV437826 and DV437799, were up-regulated by cadmium exposure and copper and cadmium co-exposure [37]. MT proteins are involved in detoxification of heavy metals and have been used as biomarkers of metal exposure for many years [106].

For $\mathrm{CuSO}_{4}$ or $\mathrm{H}_{2} \mathrm{O}_{2}$ exposure, the genes had similar expression pattern. Both chemicals are known to induce oxidative stress [107-110]. $\mathrm{CuSO}_{4}$ and $\mathrm{H}_{2} \mathrm{O}_{2}$ induced gene expression of glutathione- $S$-transferase (GST), serine proteinase inhibitor (Serpins), and alcohol dehydrogenase (ADH). $\mathrm{CuSO}_{4}$ also up-regulate lysosomal thiol reductase and expressed sequence tag, the flamingo homolog was up-regulated by $\mathrm{H}_{2} \mathrm{O}_{2}$ exposure. Pentachlorophenol (PCP) exposure induced ferritin-encoding gene, and beta-naphthoflavone induced gene encoding cathepsin L-like protease [38].

GST is also the biomarker of exposures to nanoparticle, fullerene. Catalase (CAT) is also the biomarker of nanoparticles. These two proteins involved in the detoxification processes during oxidative stress, are commonly used biomarkers in toxicity tests and indicate the early alteration of response to pollutants. The GST and CAT levels were induced in fullerene $\mathrm{nC}_{60}$, fullerenol $\mathrm{C}_{60}(\mathrm{OH})_{24}$, and titanium dioxide $\left(\mathrm{TiO}_{2}\right)$ exposure by the daphnids. Fullerene related to functionalization of nanoparticles and $\mathrm{TiO}_{2}$ is the core structure of the nanoparticles. Both functionalization and core structure affect GSH and CAT expression [103,111,112].

In a study focusing on $\mathrm{Zn}$ exposure, large numbers of genes were up- and down-regulated. Transcription- and translation-related genes and all vitellogenin-related genes were down-regulated while oxidative stress responsive genes (such as glutathione- $S$-transferase and peroxiredoxin) and other different types of metabolism-related genes were up-regulated, in comparison to the control [92]. Ribosomal proteins were both up- and down-regulated [92].

In a study of BPA toxicity using microarray techniques and Blast2GO, Jeong et al. [42] elucidated the molecular mechanisms by altered genomic responses, the molecular functions, and biological processes. They selected several candidate biomarkers which were related to BPA exposure. The 
reproductive activity of D. magna has been related to the function of molting and chitinase activity [105]. Genes related to chitin activity, chitin deacetylase 2 isoform A (NP_001096047), chitin binding domain-containing protein (ABU80624), chitin binding protein 4 (BAI44118), and encoding cuticle protein (cuticle protein 1b) were up-regulated. Serine protease encoding gene, serine protease 13 (ABZ04021), serine protease H82 (EFA11957), and serine proteinase stubbles (EFN83787, EGI65883), were also up-regulated. Various proteolytic enzymes, such as serine protease can be affected molting cycle of Daphnia causing degradation of exoskeleton [102,113]. When vitellogenin is fused with superoxide dismutase, it is down-regulated and influences embryo development and reproduction of daphnia by providing nourishment for growing embryos [114].

\section{Adverse Outcomes from Environmental Stressor Exposure}

Various toxicants such as endocrine disrupting chemicals, heavy metals, pharmaceutical drugs, and organic compounds that are widely distributed in environment can perturb the ecologically relevant organisms. These toxicants disturb ecosystems by influencing organisms at the bottom of the ecological pyramid. When the organisms are affected, the entire ecological pyramid can collapse. Therefore the base of ecosystem is crucial for the entire web of living things, including humans. Studies on the toxic effect using the daphnia systems have been carried out recently. Daphnia is a model species to study aquatic environmental toxicity designated in OECD toxicity test guideline $[115,116]$.

Endocrine disrupting chemicals (EDCs) interact with various receptors, such as the estrogen receptor (ER), androgen receptor and aryl-hydrocarbon receptor [117,118]. EDCs have an effect on reproduction by reducing the proportion of juveniles and by producing the male daphnia [119-121]. Heavy metal contaminants usually have negative effects on the development of population growth rate, longevity, and reproduction [6]. Organic compounds and drugs also have detrimental effects on reproduction and development impacting fecundity, abnormality of embryogenesis, and molting [104,122]. Table 1 summarizes studies of the effects of toxicants (i.e., EDCs, heavy metals, pharmaceutical drugs, organic compounds, and nanoparticles) on daphnia system. 
Table 1. Toxicological studies using daphnia system in response to potential environmental stressors including endocrine disrupting chemicals (EDCs), heavy metals, organic compounds, pharmaceutical drugs, and nanoparticles.

\begin{tabular}{|c|c|c|c|c|}
\hline Chemicals & Species & Chemical Exposure & Effect & Reference \\
\hline \multirow{4}{*}{ EDCs } & Daphnia magna & Nonylphenol at $0.024 \mathrm{mg} / \mathrm{L}$ for $48 \mathrm{~h}$ & Abnormal proportion of juveniles & {$[119]$} \\
\hline & Daphnia magna & Juvenile hormone at $330 \mathrm{ng} / \mathrm{L}$ for 21 days & Production of male offspring & {$[121]$} \\
\hline & Ceriodaphnia dubia & Styrene at $0.04-1.7 \mu \mathrm{g} / \mathrm{L}$ for 7 days & Mortality and reduced fertility & {$[120]$} \\
\hline & Daphnia magna & Bisphenol $\mathrm{A}$ at 6.67 and $10 \mathrm{mg} / \mathrm{L}$ for 21 days & Reduced offspring production & {$[42]$} \\
\hline \multirow{3}{*}{ Heavy metals } & Daphnia magna & Cadmium at 6,20, and $37 \mu \mathrm{g} / \mathrm{L}$ for $24 \mathrm{~h}$ & Reduced survival and somatic growth & {$[39]$} \\
\hline & Daphnia magna & Cadmium chloride at $71 \mu \mathrm{g} / \mathrm{L}$ for $24 \mathrm{~h}$ & $\begin{array}{l}\text { Increased mortality, reduced survival, depleted } \\
\text { glutathione level, and induced oxidative stress }\end{array}$ & {$[75]$} \\
\hline & $\begin{array}{c}\text { Ceriodaphnia dubia } \\
\text { and Daphnia carinata }\end{array}$ & $\begin{array}{l}\text { Copper, lead, zinc (at } 1.3,1.1,13.0 \mathrm{mg} / \mathrm{L}, \\
\text { respectively) for } 48 \mathrm{~h} \text { or } 7 \text { days }\end{array}$ & $\begin{array}{l}\text { Increased mortality and } \\
\text { reduced reproduction ability }\end{array}$ & {$[123]$} \\
\hline \multirow{5}{*}{$\begin{array}{l}\text { Organic } \\
\text { compounds }\end{array}$} & Daphnia pulex & Organic selenium at $0.025 \mathrm{mg} / \mathrm{L}$ for $48 \mathrm{~h}$ & Death, immobility, and molting delay & {$[122]$} \\
\hline & Daphnia magna & $\begin{array}{l}\text { Propiconazole (pesticide) at } \\
1 \mu \mathrm{g} / \mathrm{L} \text { for } 4 \text { and } 8 \text { days }\end{array}$ & $\begin{array}{l}\text { Impaired adult growth, decreased offspring } \\
\text { development, impaired oocyte maturation, } \\
\text { and interrupted resulting reproduction }\end{array}$ & {$[41]$} \\
\hline & Daphnia magna & Fenvalerate (insecticide) at $0.6 \mu \mathrm{g} / \mathrm{L}$ for $24 \mathrm{~h}$ & $\begin{array}{l}\text { Increased mortality, reduced survival, increased arginine } \\
\text { phosphate level, and disrupted amino sugar metabolism }\end{array}$ & {$[75]$} \\
\hline & Daphnia magna & $\begin{array}{l}\text { Uncoupler of oxidative phosphorylation } \\
\text { 2,4-dinitrophenol at } 1.5 \mathrm{mg} / \mathrm{L} \text { for } 24 \mathrm{~h}\end{array}$ & $\begin{array}{l}\text { Increased mortality, reduced survival, and } \\
\text { increased arginine phosphate level }\end{array}$ & {$[75]$} \\
\hline & Daphnia magna & $\begin{array}{l}\text { Alkylpolyglucosides (GCP } 650, \mathrm{GCP} 600, \\
\text { GCP 215) at } \mathrm{IC}_{50}(29,14,111 \mathrm{mg} / \mathrm{L} \\
\text { respectively) for } 24 \mathrm{~h}\end{array}$ & Increased immobility & {$[124]$} \\
\hline
\end{tabular}


Table 1. Cont.

\begin{tabular}{|c|c|c|c|c|}
\hline Chemicals & Species & Chemical Exposure & Effect & Reference \\
\hline \multirow{3}{*}{ Drugs } & Daphnia magna & $\begin{array}{l}\text { Ibuprofen (non-steroidal anti-inflammatory } \\
\text { drug or NSAID) at } 20,40,80 \mathrm{mg} / \mathrm{L} \text { for } 8 \text { days }\end{array}$ & Reduced fecundity and arrested early embryogenesis & {$[104]$} \\
\hline & Daphnia magna & $\begin{array}{l}\text { Beta-blocker anti-hypertension drug propanolol } \\
\text { at } 1.4 \mathrm{mg} / \mathrm{L} \text { for } 24 \mathrm{~h}\end{array}$ & $\begin{array}{l}\text { Increased mortality, reduced survival, } \\
\text { and disrupted fatty acid metabolism and eicosanoid biosynthesis }\end{array}$ & {$[75]$} \\
\hline & Daphnia magna & $\begin{array}{l}\text { Mefenamicacid at } \mathrm{EC}_{50}(17.16 \mathrm{mg} / \mathrm{L}) \text { for } 48 \mathrm{~h} \text { and } \\
1 \mathrm{mg} / \mathrm{L} \text { for } 21 \text { days }\end{array}$ & Increased immobility and reduced offspring production & [125] \\
\hline \multirow{9}{*}{ Nanoparticles } & Daphnia magna & $\begin{array}{c}\text { Silver nanoparticles with surface } \\
\text { coating at } \mathrm{LC}_{50}(0.88 \mu \mathrm{g} / \mathrm{L}) \text { for } 48 \mathrm{~h}\end{array}$ & Increased mortality and reduced survival & {$[126]$} \\
\hline & Daphnia magna & $\begin{array}{l}\text { Polyvinylpyrrolidone-coated silver } \\
\text { nanoparticles at } \mathrm{LC}_{50}(0.18 \mathrm{mg} / \mathrm{L}) \text { for } 24 \mathrm{~h}\end{array}$ & $\begin{array}{l}\text { Increased mortality, reduced survival, } \\
\text { disrupted proteolysis and cell cycle }\end{array}$ & {$[44]$} \\
\hline & Daphnia magna & $\begin{array}{c}\text { Coated silver nanoparticles (Ag-GAs, Ag-PEGs, } \\
\text { and Ag-PVPs) at } \operatorname{LC}_{50}(3.41,3.16,14.81 \mu \mathrm{g} / \mathrm{L} \text {, } \\
\text { respectively) for } 48 \mathrm{~h}\end{array}$ & Increased mortality & {$[127]$} \\
\hline & Daphnia magna & $\begin{array}{c}\text { Collargol (protein-coated nano } \mathrm{Ag} \text { ) and } \mathrm{AgNO}_{3} \\
\text { nanoparticles at } \mathrm{EC}_{50}(20-27 \mathrm{ppb}) \text { for } 48 \mathrm{~h}\end{array}$ & Increased immobility & [128] \\
\hline & Daphnia magna & $\begin{array}{l}\mathrm{Ag} \text { and } \mathrm{CuO} \text { nanoparticles at } \mathrm{EC}_{50} \\
\text { (3.8 and } 2.6 \mathrm{mg} / \mathrm{L} \text {, respectively) for } 24 \mathrm{~h}\end{array}$ & Increased immobility & [129] \\
\hline & Daphnia magna & $\begin{array}{l}\text { Titanium dioxide nanoparticles } \\
\text { at } 0.01-10 \mathrm{mg} / \mathrm{L} \text { for } 48 \mathrm{~h}\end{array}$ & Reduced survival offspring production, and digestion ability & {$[130]$} \\
\hline & Daphnia magna & Nano and bulk titanium dioxide at $20 \mathrm{~g} / \mathrm{L}$ for $48 \mathrm{~h}$ & Undetectable toxicity & {$[131]$} \\
\hline & Daphnia magna & $\begin{array}{l}\text { Bulk } \mathrm{CuO} \text {, nano } \mathrm{CuO} \text { and } \mathrm{CuSO}_{4} \text { at } \mathrm{L}(\mathrm{E}) \mathrm{C}_{50} \\
(165,3.2,0.17 \mathrm{mg} / \mathrm{L} \text {, respectively) for } 48 \mathrm{~h}\end{array}$ & Increased immobility & [131] \\
\hline & Daphnia magna & $\begin{array}{l}\text { Bulk } \mathrm{ZnO} \text {, nano } \mathrm{ZnO} \text { and } \mathrm{ZnSO}_{4} \cdot 7 \mathrm{H}_{2} \mathrm{O} \text { at } \mathrm{L}(\mathrm{E}) \mathrm{C}_{50} \\
(1.8,1.9,1.1 \mathrm{mg} / \mathrm{L} \text {, respectively) for } 48 \mathrm{~h}\end{array}$ & Increased immobility & {$[131]$} \\
\hline
\end{tabular}




\section{Perspectives}

Daphnia offers advantages for toxicological investigation of multiple stressors owing to high growth rate, high sensitivity to environmental changes, wide spatial distribution, parthenogenetic life cycle, and availability of omics-based tools [122]. In particular, its unique parthenogenesis facilitates the study of epigenetic effects without profound genetic differences [132,133]. Epigenetically regulated-sex determination and sexual reproduction are undergone toward harsh environmental conditions.

Mapping the phenotype to the genotype in Daphnia system is considerable challenge. Genomic responses to genetic and environmental stressors as well as environmental impact on the phenotype have been pursued [134-136]. Integration of genome sequencing with the functional genomic tools provides a better insight on phenotypic evolution, mechanistic elucidation of the evolutionary novel traits, evolutionary adaptation, and regulatory pathways underlying to adaptive evolution.

In the context of ecological risk assessment regarding complex mixtures, genomic tools and fingerprinting approaches offer exceptional platform [40]. Several transcriptomic research projects that use either simple mixtures of particular chemicals or complex mixtures like entire effluents have emerged to evaluate these capabilities, suggesting that the microarray approach was informative [137,138]. A mixture consisting of four chemicals was used to examine the hypothesis that salient transcriptomic responses of individual chemicals could be retained in mixtures, including compounds with dissimilar modes of toxicity $[139,140]$. This is one of the concepts to applying transcriptome signatures/fingerprints in environmental exposure diagnosis. Metabolomic analyses might complement with phenotypic data or transcriptomic data, while systemic ontologies and pathway analysis software for metabolomics has been developed even less in comparison to transcriptomics and proteomics. However, metabolomics likely has as much potential as transcriptomics or proteomics for utility to ecological risk assessment.

Understanding of genetic and epigenetic mechanisms underlying phenotypic responses to environment (i.e., sex determination, sexual reproduction, helmets, and neckteeth) offers great benefit. In addition to DNA methylation, extensive researches on histone modification, RNAi, and changes in DNA methylation toward environmental stressors throughout developmental stages are necessary. Using Daphnia model, the epigenetic discriminatory between sexual and asexual as well as stressor-exposed and non-exposed daphnid individuals will be warranted with potential applications in the area of evolutionary and developmental biology.

\section{Acknowledgments}

This research was supported by a grant from "The Ecoinnovation Project" (412-112-011), by the Korea Ministry of Environment. This research project was also supported by a grant from Mahidol University, Thailand, and by a grant from the Faculty of Environment and Resource Studies, Mahidol University, Thailand.

\section{Conflicts of Interest}

These authors declare no conflict of interest. 


\section{References}

1. Bartosiewicz, M.; Penn, S.; Buckpitt, A. Applications of gene arrays in environmental toxicology: Fingerprints of gene regulation associated with cadmium chloride, benzo(a)pyrene, and trichloroethylene. Environ. Health Perspect. 2001, 109, 71-74.

2. Snape, J.R.; Maund, S.J.; Pickford, D.B.; Hutchinson, T.H. Ecotoxicogenomics: The challenge of integrating genomics into aquatic and terrestrial ecotoxicology. Aquat. Toxicol. 2004, 67, 143-154.

3. Miracle, A.L.; Ankley, G.T. Ecotoxicogenomics: Linkages between exposure and effects in assessing risks of aquatic contaminants to fish. Reprod. Toxicol. 2005, 19, 321-326.

4. Iguchi, T.; Watanabe, H.; Katsu, Y. Application of ecotoxicogenomics for studying endocrine disruption in vertebrates and invertebrates. Environ. Health. Perspect. 2006, 114, 101-105.

5. Watanabe, H.; Iguchi, T. Using ecotoxicogenomics to evaluate the impact of chemicals on aquatic organisms. Mar. Biol. 2006, 149, 107-115.

6. Altshuler, I.; Demiri, B.; Xu, S.; Constantin, A.; Yan, N.D.; Cristescu, M.E. An Integrated multi-disciplinary approach for studying multiple stressors in freshwater ecosystems: Daphnia as a model organism. Integr. Comp. Biol. 2011, 51, 623-633.

7. Nuwaysir, E.F.; Bittner, M.; Trent, J.; Barrett, J.C.; Afshari, C.A. Microarrays and toxicology: The advent of toxicogenomics. Mol. Carcinog. 1999, 24, 153-159.

8. Kurelec, B. The genotoxic disease syndrome. Mar. Environ. Res. 1993, 35, 341-348.

9. Oakshott, J.G. Selection at the Adh locus in Drosophila melanogaster imposed by environmental ethanol. Genet. Res. 1976, 26, 265-274.

10. Hawkins, A.J.S.; Rusia, J.; Bayne, B.L.; Day, A.J. The metabolic/physiological basis of genotype-dependent mortality during copper exposure in Mytilus edulis. Mar. Environ. Res. 1989, 28, 139-144.

11. Schat, H.; Ten Bookum, W.M. Genetic control of copper tolerance in Silene vulgaris. Heredity 1992, 68, 219-229.

12. Hebert, P.D.N. The population biology of Daphnia (Crustacea, Daphnidae). Biol. Rev. 1978, 53, $387-426$.

13. Lampert, W. Daphnia: Model herbivore, predator and prey. Pol. J. Ecol. 2006, 54, 607-620.

14. Cristescu, M.E.; Colbourne, J.K.; Radivojac, J.; Lynch, M. A microsatellite-based linkage map of the water flea Daphnia pulex: On the prospect of crustacean genomics. Genomics 2006, 88, 415-430.

15. Eads, B.D.; Andrews, J.; Colbourne, J.K. Ecological genomics in Daphnia: Stress responses and environmental sex determination. Heredity 2008, 100, 184-190.

16. Colbourne, J.K.; Hebert, P.D.N.; Taylor, D.J. Evolutionary origins of phenotypic diversity in daphnia. In Molecular Evolution and Adaptive Radiation; Givnish, T.J., Sytsma, K.J., Eds.; Cambridge University Press: Cambridge, UK, 1997; pp. 163-188.

17. Schindler, D.W. Detecting ecosystem responses to anthropogenic stress. Can. J. Fish. Aquat. Sci. 1987, 44, 6-25.

18. Hebert, P.D.N.; Crease T. Clonal diversity in populations of Daphnia pulex reproducing by obligate parthenogenesis. Heredity 1983, 51, 353-369. 
19. Stich, H.B.; Lampert, W. Growth and reproduction of migrating and non-migrating Daphnia species under simulated food and temperature conditions of diurnal vertical migration. Oecologia 1984, 61, 192-196.

20. Dawidowicz, P.; Loose, C.J. Metabolic costs during predator-induced diel vertical migration of Daphnia. Limnol. Oceanogr. 1992, 37, 1589-1595.

21. Gerhardt, A.; de Bisthoven, B.L.; Soares, A.M.V. Evidence for the stepwise stress model: Gambusia holbrooki and Daphnia magna under acid mine drainage and acidified reference water stress. Environ. Sci. Technol. 2005, 39, 4150-4158.

22. Tollrian, R. Neckteeth formation in Daphnia pulex as an example of continuous phenotypic plasticity: Morphological effects of Chaoborus kairomone concentration and their quantification. J. Plankton Res. 1993, 15, 1309-1318.

23. Tautz, D. Not just another genome. BMC. Biol. 2011, 9, 8 .

24. Fryer, G. Functional morphology and the adaptive radiation of the Daphnidae (Branchiopoda: Anomopoda). Philos. Trans. R. Soc. B. 1991, 331, 1-99.

25. Hebert, P.D.N. The Daphnia of North America: An Illustrated Fauna; University of Guelph: Guelph, ON, Canada, 1995.

26. Wellborn, G.A.; Skelly, D.K.; Werner, E.E. Mechanisms creating community structure across a freshwater habitat gradient. Annu. Rev. Ecol. Syst. 1996, 27, 337-363.

27. Crease, T.J.; Lee, S.K.; Yu, S.L.; Spitze, K.; Lehman, N.; Lynch, M. Allozyme and mtDNA variation in populations of the Daphnia pulex complex from both sides of the Rocky Mountains. Heredity 1997, 79, 242-251.

28. Pfrender, M.E.; Spitze, K.; Lehman, N. Multi-locus genetic evidence for rapid ecologically based speciation in Daphnia. Mol. Ecol. 2000, 9, 1717-1735.

29. Boverhof, D.R.; Gollapudi, B.B. Applications of Toxicogenomics. In Safety Evaluation and Risk Assessment, 1st ed.; Wiley: Singapore, 2011.

30. Larkin, P.; Villeneuve, D.L.; Knoebl, I.; Miracle, A.L.; Carter, B.J.; Liu, L.; Denslow, N.D.; Ankley, G.T. Development and validation of a 2000-gene microarray for the fathead minnow (Pimephales promelas). Environ. Toxicol. Chem. 2007, 26, 1497-1506.

31. Morgan, M.B.; Edge, S.E.; Snell, T.W. Profiling differential gene expression of corals along a transect of waters adjacent to the Bermuda municipal dump. Mar. Pollut. Bull. 2005, 51, 524-533.

32. Park, H.R.; Yang, H.; Kim, G.D.; Son, G.W.; Park, Y.S. Microarray analysis of gene expression in 3-methylcholanthrene-treated human endothelial cells. Mol. Cell. Toxicol. 2014, 10, 19-27.

33. Carney, S.A.; Chen, J.; Burns, C.G.; Xiong, K.M.; Peterson, R.E.; Heideman, W. Aryl hydrocarbon receptor activation produces heart-specific transcriptional and toxic responses in developing zebrafish. Mol. Pharmacol. 2006, 70, 549-561.

34. Santos, E.M.; Paull, G.C.; van Look, K.J.; Workman, V.L.; Holt, W.V.; van Aerle, R.; Kille, P.; Tyler, C.R. Gonadal transcriptome responses and physiological consequences of exposure to estrogen in breeding zebrafish (Danio rerio). Aquat. Toxicol. 2007, 83, 134-142.

35. Wang, R.L.; Bencic, D.; Biales, A.; Lattier, D.; Kostich, M.; Villeneuve, D.; Ankley, G.T.; Lazorchak, J.; Toth, G. DNA microarray-based ecotoxicological biomarker discovery in a small fish model species. Environ. Toxicol. Chem. 2008, 27, 664-675. 
36. Heckmann, L.H.; Connon, R.; Hutchinson, T.H.; Maund, S.J.; Sibly, R.M.; Callaghan, A. Expression of target and reference genes in Daphnia magna exposed to ibuprofen. BMC Genomics 2006, 7, 175.

37. Poynton, H.C.; Varshavsky, J.R.; Chang, B.; Cavigiolio, G.; Chan, S.; Holman, P.S.; Loguinov, A.V.; Bauer, D.J.; Komachi, K.; Theil, E.C.; et al. Daphnia magna ecotoxicogenomics provides mechanistic insights into metal toxicity. Environ. Sci. Technol. 2007, 41, 1044-1050.

38. Watanabe, H.; Takahashi, E.; Nakamura, Y.; Oda, S.; Tatarazako, N.; Iguchi, T. Development of a Daphnia magna DNA microarray for evaluating the toxicity of environmental chemicals. Environ. Toxicol. Chem. 2007, 26, 669-676.

39. Connon, R.; Hooper, H.L.; Sibly, R.M.; Lim, F.L.; Heckmann, L.H.; Moore, D.J.; Watanabe, H.; Soetaert, A.; Cook, K.; Maund, S.J.; et al. Linking molecular and population stress responses in Daphnia magna exposed to cadmium. Environ. Sci. Technol. 2008, 42, 2181-2188.

40. Garcia-Reyero, N.; Griffitt, R.J.; Liu, L. Construction of a robust microarray from a non-model species (largemouth bass) using pyrosequencing technology. J. Fish. Biol. 2008, 72, 2354-2376.

41. Soetaert, A.; Moens, L.N.; van der Ven, K.; van Leemput, K.; Naudts, B.; Blust, R.; de Coen, W.M. Molecular impact of propiconazole on Daphnia magna using a reproduction-related cDNA array. Comp. Biochem. Physiol. C Toxicol. Pharmacol. 2006, 142, 66-76.

42. Jeong, S.W.; Lee, S.M.; Yum, S.S.; Iguchi, T.; Seo, Y.R. Genomic expression responses toward bisphenol-A toxicity in Daphnia magna in terms of reproductive activity. Mol. Cell. Toxicol. 2013, 9, 149-158.

43. Dong, Y.; Zhai, L.; Zhang, L.; Jia, L.; Wang, X. Bisphenol A impairs mitochondrial function in spleens of mice via oxidative stress. Mol. Cell. Toxicol. 2013, 9, 401-406.

44. Poynton, H.C.; Lazorchak, J.M.; Impellitteri, C.A.; Blalock, B.J.; Rogers, K.; Allen, H.J.; Loguinov, A.; Heckman, J.L.; Govindasmawy, S. Toxicogenomic responses of nanotoxicity in Daphnia magna exposed to silver nitrate and coated silver nanoparticles. Environ. Sci. Technol. 2012, 46, 6288-6296.

45. Villeneuve, D.L.; Larkin, V.P.; Knoebl, I.; Miracle, A.L.; Kahl, M.D.; Jensen, K.M.; Makynen, E.A.; Durhan, E.J.; Carter, B.J.; Denslow, N.D.; et al. A graphical systems model to facilitate hypothesis-driven ecotoxicogenomics research on the teleost brain-pituitary-gonadal axis. Environ. Sci. Technol. 2007, 41, 321-330.

46. Villeneuve, D.L.; Knoebl, I.; Larkin, P.; Miracle, A.L.; Carter, B.J.; Denslow, N.D.; Ankley, G.T. Altered gene expression in the brain and liver of female fathead minnows Pimephales promelas Rafinesque exposed to fadrozole. J. Fish. Biol. 2008, 72, 2281-2340.

47. Denslow, N.D.; Kocerha, J.; Sepúlveda, M.S.; Gross, T.; Holm, S.E. Gene expression fingerprints of largemouth bass (Micropterus salmoides) exposed to pulp and paper mill effluents. Mutat. Res. 2004, 552, 19-34.

48. Williams, T.D.; Diab, A.M.; George, S.G.; Godfrey, R.E.; Sabine, V.; Conesa, A.; Minchin, S.D.; Watts, P.C.; Chipman, J.K. Development of the GENIPOL European flounder (Platichthys flesus) microarray and determination of temporal transcriptional responses to cadmium at low dose. Environ. Sci. Technol. 2006, 40, 6479-6488.

49. Yeung, L.W.Y.; Guruge, K.S.; Yamanaka, N.; Miyazaki, S.; Lam, P.K.S. Differential expression of chicken hepatic genes responsive to PFOA and PFOS. Toxicology 2007, 237, 111-125. 
50. Krasnov, A.; Koskinen, H.; Pehkonen, P.; Rexroad, C.E.; Afanasyev, S.; Mölsä, H. Gene expression in the brain and kidney of rainbow trout in response to handling stress. BMC Genomics 2005, 6, 3.

51. Krasnov, A.; Koskinen, H.; Pehkonen, P.; Rexroad, C.; Afanasyev, S.; Mölsä, H.; Oikari, A. Transcriptome responses to carbon tetrachloride and pyrene in the kidney and liver of juvenile rainbow trout (Oncorhynchus mykiss). Aquat. Toxicol. 2005, 74, 70-81.

52. Kassahn, K.S.; Crozier, R.H.; Ward, A.C.; Stone, G.; Caley, M.J. From transcriptome to biological function: Environmental stress in an ectothermic vertebrate, the coral reef fish Pomacentrus moluccensis. BMC Genomics 2007, 8, 358.

53. Lam, S.H.; Winata, C.L.; Tong, Y.; Korzh, S.; Lim, W.S.; Jan Spitsbergen, V.K.; Mathavan, S.; Miller, L.D.; Liu, E.T. Transcriptome kinetics of arsenic-induced adaptive response in zebrafish liver. Physiol. Genomics 2006, 27, 351-361.

54. Volz, D.C.; Hinton, D.E.; Law, J.M.; Kullman, S.W. Dynamic gene expression changes precede dioxin-induced liver pathogenesis in medaka fish. Toxicol. Sci. 2006, 89, 524-534.

55. Soetaert, A.; van der Ven, K.; Moens, L.N.; Vandenbrouck, T.; van Remortel, P.; de Coen, W.M. Daphnia magna and ecotoxicogenomics: Gene expression profiles of the anti-ecdysteroidal fungicide fenarimol using energy-, molting- and life stage-related cDNA libraries. Chemosphere 2007, 67, 60-71.

56. Watanabe, H.; Tatarazako, N.; Oda, S.; Nishide, H.; Uchiyama, I.; Morita, M.; Iguchi, T. Analysis of expressed sequence tags of the water flea Daphnia magna. Genome 2005, 48, 606-609.

57. Margulies, M.; Egholm, M.; Altman, W.E.; Attiya, S.; Bader, J.S.; Bemben, L.A.; Berka, J.; Braverman, M.S.; Chen, Y.J.; Chen, Z.T.; et al. Genome sequencing in microfabricated high-density picolitre reactors. Nature 2005, 437, 376-380.

58. Hardy, S.; Legagneux, V.; Audic, Y.; Paillard, L. Reverse genetics in eukaryotes. Biol. Cell 2010, 102, 561-580.

59. Martyniuk, C.J.; Trudeau, V.L. Fish endocrinology meets functional genomics: What exactly is the message? Gen. Comp. Endocrinol. 2009, 164, 132-134.

60. Kato, Y.; Kobayashi, K.; Watanabe, H.; Iguchi, T. Environmental sex determination in the branchipod crustacean Daphnia magna: Deep conservation of a double-sex gene in the sex-determining pathway. PLoS Genet. 2011, 7, e1001345.

61. Wetmore, B.A.; Merrick, B.A. Toxicoproteomics: Proteomics applied to toxicology and pathology. Toxicol. Pathol. 2004, 32, 619-642.

62. Shepard, J.L.; Olsson, B.; Tedengren, M.; Bradley, B.P. Protein expression signatures identified in Mytilus edulis exposed to PCBs, copper and salinity stress. Mar. Environ. Res. 2000, 50, 337-340.

63. Rodríguez-Ortega, M.J.; Grøsvik, B.E.; Rodríguez-Ariza, A.; Goksøyr, A.; López-Barea, J. Changes in protein expression profiles in bivalve molluscs (Chamaelea gallina) exposed to four model environmental pollutants. Proteomics 2003, 3, 1535-1543.

64. Shrader, E.A.; Henry, T.R.; Greeley, M.S., Jr.; Bradley, B.P. Proteomics in zebrafish exposed to endocrine disrupting chemicals. Ecotoxicology 2003, 12, 485-458.

65. Hogstrand, C.; Balesaria, S.; Glover, C.N. Application of genomics and proteomics for study of the integrated response to zinc exposure in a non-model fish species, the rainbow trout. Comp. Biochem. Physiol. B Biochem. Mol. Biol. 2002, 133, 523-535. 
66. Bjørnstad, A.; Larsen, B.K.; Skadsheim, A.; Jones, M.B.; Andersen, O.K. The potential of ecotoxicoproteomics in environmental monitoring: Biomarker profiling in mussel plasma using Protein Chip array technology. J. Toxicol. Environ. Health A 2006, 69, 77-96.

67. Le, T.H.; Lim, E.S.; Hong, N.H.; Lee, S.K.; Shim, Y.S.; Hwang, J.R.; Kim, Y.H.; Min, J. Proteomic analysis in Daphnia magna exposed to $\mathrm{As}(\mathrm{III}), \mathrm{As}(\mathrm{V})$ and $\mathrm{Cd}$ heavy metals and their binary mixtures for screening potential biomarkers. Chemosphere 2013, 93, 2341-2348.

68. Rainville, L.C.; Carolan, D.; Varela, A.C.; Doyle, H.; Sheehan, D. Proteomic evaluation of citrate-coated silver nanoparticles toxicity in Daphnia magna. Analyst 2014, 7, 1678-1686.

69. Choi, Y.S.; Lee, M.Y.; David, A.E.; Park, Y.S. Nanoparticles for gene delivery: Therapeutic and toxic effects. Mol. Cell. Toxicol. 2014, 10, 1-8.

70. Ralston-Hooper, K.; Hopf, A.; Oh, C.; Zhang, X.; Adamec, J.; Sepúlveda, M.S. Development of GCxGC/TOF-MS metabolomics for use in ecotoxicological studies with invertebrates. Aquat. Toxicol. 2008, 2, 48-52.

71. Yoo, G.; Jeong, S.H.; Ryu, W.I.; Lee, H.; Kim, J.H.; Bae, H.C.; Son, S.W. Gene expression analysis reveals a functional role for the Ag-NPs-induced Egr-1 transcriptional factor in human keratinocytes. Mol. Cell. Toxicol. 2014, 10, 149-156.

72. Park, Y.H.; Bae, H.C.; Jang, Y.; Jeong, S.H.; Lee, H.N.; Ryu, W.I.; Yoo, M.G.; Kim, Y.R.; Kim, M.K.; Lee, J.K.; et al. Effect of the size and surface charge of silica nanoparticles on cutaneous toxicity. Mol. Cell. Toxicol. 2013, 9, 67-74.

73. Bundy, J.G.; Keun, H.C.; Sidhu, J.K.; Spurgeon, D.J.; Svendsen, C.; Kille, P.; Morgan, A.J. Metabolic profile biomarkers of metal contamination in a sentinel terrestrial species are applicable across multiple sites. Environ. Sci. Technol. 2007, 41, 4458-4464.

74. Taylor, N.S.; Weber, R.J.M.; Southam, A.D.; Payne, T.G.; Hrydziuszko, O.; Arvanitis, T.N.; Viant, M.R. A new approach to toxicity testing in Daphnia magna: Application of high throughput FT-ICR mass spectrometry metabolomics. Metabolomics 2009, 5, 44-58.

75. Taylor, N.S.; Weber, R.J.; White, T.A.; Viant, M.R. Discriminating between different acute chemical toxicities via changes in the daphnid metabolome. Toxicol. Sci. 2010, 118, 307-317.

76. Stohs, S.J.; Bagchi, D. Oxidative mechanisms in the toxicity of metal ions. Free Radic. Biol. Med. 1995, 18, 321-336.

77. Ray, D.E.; Fry, J.R. A reassessment of the neurotoxicity of pyrethroid insecticides. Pharmacol. Ther. 2006, 111, 174-193.

78. Drysdale, G.R.; Cohn, M. Mode of action of 2,4-dinitrophenol in uncoupling oxidative phosphorylation. J. Biol. Chem. 1958, 233, 1574-1577.

79. Huggett, D.B.; Brooks, B.W.; Peterson, B.; Foran, C.M.; Schlenk, D. Toxicity of select beta adrenergic receptor-blocking pharmaceuticals (b-blockers) on aquatic organisms. Arch. Environ. Contam. Toxicol. 2002, 43, 229-235.

80. Poynton, H.C.; Taylor, N.S.; Hicks, J.; Colson, K.; Chan, S.; Clark, C.; Scanlan, L.; Loguinov, A.V.; Vulpe, C.; Viant, M.R. Metabolomics of microliter hemolymph samples enables an improved understanding of the combined metabolic and transcriptional responses of Daphnia magna to cadmium. Environ. Sci. Technol. 2011, 45, 3710-3717. 
81. Nagato, E.G.; D’eon, J.C.; Lankadurai, B.P.; Poirier, D.G.; Reiner, E.J.; Simpson, A.J.; Simpson, M.J. ${ }^{1} \mathrm{H}$ NMR-based metabolomics investigation of Daphnia magna responses to sub-lethal exposure to arsenic, copper and lithium. Chemosphere 2013, 93, 331-337.

82. Ho, D.H.; Burggren, W.W. Epigenetics and transgenerational transfer: A physiological perspective. J. Exp. Biol. 2010, 213, 3-16.

83. Vandegehuchte, M.B.; Janssen, C.R. Epigenetics and its implications for ecotoxicology. Ecotoxicology 2011, 20, 607-624.

84. Jaenisch, R.; Bird, A. Epigenetic regulation of gene expression: How the genome integrates intrinsic and environmental signals. Nat. Genet. 2003, 33, 245-254.

85. Santos, K.F.; Mazzola, T.N.; Carvalho, H.F. The prima donna of epigenetics: The regulation of gene expression by DNA methylation. Braz. J. Med. Biol. Res. 2005, 38, 1531-1541.

86. Fuks, F. DNA methylation and histone modifications: Teaming up to silence genes Curr. Opin. Genet. Dev. 2005, 15, 490-495.

87. Lennartsson, A.; Ekwall, K. Histone modification patterns and epigenetic codes. Biochim. Biophys. Acta 2009, 1790, 863-868.

88. Lippman, Z.; Martienssen, R. The role of RNA interference in heterochromatic silencing. Nature 2004, 431, 364-370.

89. Carthew, R.W.; Sontheimer, E.J. Origins and Mechanisms of miRNAs and siRNAs. Cell 2009, $136,642-655$.

90. Reamon-Buettner, S.M.; Mutschler, V.; Borlak, J. The next innovation cycle in toxicogenomics: Environmental epigenetics. Mutat. Res. 2008, 659, 158-165.

91. Krieg, A.J.; Rankin, E.B.; Chan, D.; Razorenova, O.; Fernandez, S.; Giaccia, A.J. Regulation of the histone demethylase JMJD1A by hypoxia-inducible factor 1 alpha enhances hypoxic gene expression and tumor growth. Mol. Cell. Biol. 2010, 30, 344-353.

92. Vandegehuchte, M.B.; Vandenbrouck, T.; Coninck, D.D.; de Coen, W.M.; Janssen, C.R. Can metal stress induce transferable changes in gene transcription in Daphnia magna? Aquat. Toxicol. 2010, 97, 188-195.

93. Aluru, N.; Karchner, S.I.; Hahn, M.E. Role of DNA methylation of AHR1 and AHR2 promoters in differential sensitivity to PCBs in Atlantic Killifish, Fundulus heteroclitus. Aquat. Toxicol. 2011, 101, 288-294.

94. Vandegehuchte, M.B.; Kyndt, T.; Vanholme, B.; Haegeman, A.; Gheysen, G.; Janssen, C.R. Occurrence of DNA methylation in Daphnia magna and influence of multigeneration Cd exposure. Environ. Int. 2009, 35, 700-706.

95. Youngson, N.A.; Whitelaw, E. Transgenerational epigenetic effects. Annu. Rev. Genomics Hum. Genet. 2008, 9, 233-257.

96. Vandegehuchte, M.B.; Lemi’ere, F.; Vanhaecke, L.; Vanden Berghe, W.; Janssen, C.R. Direct and transgenerational impact on Daphnia magna of chemicals with a known effect on DNA methylation. Comp. Biochem. Physiol. C Toxicol. Pharmacol. 2010, 151, 278-285.

97. Vandegehuchte, M.B.; Vandenbrouck, T.; de Coninck, D.; de Coen, W.M.; Janssen, C.R. Gene transcription and higher-level effects of multigenerational $\mathrm{Zn}$ exposure in Daphnia magna. Chemosphere 2010, 80, 1014-1020. 
98. Eads, B.D.; Colbourne, J.K.; Bohuski, E.; Andrews, J. Profiling sex-biased gene expression during parthenogenetic reproduction in Daphnia pulex. BMC Genomics 2007, 8, 464.

99. Agrawal1, A.A.; Laforsch, C.; Tollrian, R. Transgenerational induction of defences in animals and plants. Nature 1999, 401, 60-63.

100. Miyakawa, H; Imai, M.; Sugimoto, N.; Ishikawa, Y.; Ishikawa, A.; Ishigaki, H.; Okada, Y.; Miyazaki, S.; Koshikawa, S.; Cornette, R.; et al. Gene up-regulation in response to predator kairomones in the water flea, Daphnia pulex. BMC Dev. Biol. 2010, 10, 45.

101. Vandegehuchte, M.B.; Lemière, F.; Janssen, C.R. Quantitative DNA-methylation in Daphnia magna and effects of multigeneration Zn exposure. Comp. Biochem. Physiol. C Toxicol. Pharmacol. 2009, $150,343-348$.

102. Soetaert, A.; Vandenbrouck, T.; van der Ven, K.; Maras, M.; van Remortel, P.; Blust, R.; de Coen, W.M. Molecular responses during cadmium-induced stress in Daphnia magna: Integration of differential gene expression with higher-level effects. Aquat. Toxicol. 2007, 83, $212-222$.

103. Klaper, R.; Crago, J.; Barr, J.; Arndt, D.; Setyowati, K.; Chen, J. Toxicity biomarker expression in daphnids exposed to manufactured nanoparticles: Changes in toxicity with functionalization. Environ. Pollut. 2009, 157, 1152-1156.

104. Heckmann, L.H.; Sibly, R.M.; Connon, R.; Hooper, H.L.; Hutchinson, T.H.; Maund, S.J.; Hill, C.J.; Bouetard, A.; Callaghan, A. Systems biology meets stress ecology: Linking molecular and organismal stress responses in Daphnia magna. Genome. Biol. 2008, 9, R40.

105. Merzendorfer, H.; Zimoch, L. Chitin metabolism in insects: Structure, function and regulation of chitin synthases and chitinases. J. Exp. Biol. 2003, 206, 4393-4412.

106. Hennig, H.F. Metal-binding proteins as metal pollution indicators. Environ. Health Perspect. 1986, $65,175-187$.

107. Gaetke, L.M.; Chow, C.K. Copper toxicity, oxidative stress, and antioxidant nutrients. Toxicology 2003, 189, 147-163.

108. Wang, Y.J.; Lee, C.C.; Chang, W.C.; Liou, H.B.; Ho, Y.S. Oxidative stress and liver toxicity in rats and human hepatoma cell line induced by pentachlorophenol and its major metabolite tetrachlorohydroquinone. Toxicol. Lett. 2001, 122, 157-169.

109. Xie, F.; Koziar, S.A.; Lampi, M.A.; Dixon, D.G.; Norwood, W.P.; Borgmann, U.; Huang, X.-D.; Greenberg, B.M. Assessment of the toxicity of mixtures of copper, 9,10-phenanthrenequinone, and phenanthrene to Daphnia magna: Evidence for a reactive oxygen mechanism. Environ. Toxicol. Chem. 2006, 25, 613-622.

110. Kim, D.K.; Song, J.W.; Park, J.D.; Choi, B.S. Copper induces the accumulation of amyloid-beta in the brain. Mol. Cell. Toxicol. 2013, 9, 57-66.

111. Park, H.G.; Yeo, M.K. Effects of $\mathrm{TiO}_{2}$ nanoparticles and nanotubes on zebrafish caudal fin regeneration. Mol. Cell. Toxicol. 2013, 9, 375-383.

112. Park, H.G.; Kim, J.I.; Kang, M.; Yeo, M.K. The effect of metal-doped $\mathrm{TiO}_{2}$ nanoparticles on zebrafish embryogenesis. Mol. Cell. Toxicol. 2014, 10, 293-301.

113. Ote, M.; Mita, K.; Kawasaki, H.; Daimon, T.; Kobayashi, M.; Shimada, T. Identification of molting fluid carboxypeptidase A (MF-CPA) in Bombyx mori. Comp. Biochem. Physiol. B Biochem. Mol. Biol. 2005, 141, 314-322. 
114. Kato, Y.; Tokishita, S.; Ohta, T.; Yamagata, H. A vitellogenin chain containing a superoxide dismutase-like domain is the major component of yolk proteins in cladoceran crustacean Daphnia magna. Gene 2004, 334, 157-165.

115. OECD/OCDE 202, OECD Guideline for Testing of Chemicals; Daphnia sp. Acute Immobilisation Test. Available online: http://www.oecd-ilibrary.org/environment/test-no-202-daphnia-sp-acuteimmobilisation-test_9789264069947-en (accessed on 28 May 2015).

116. OECD/OCDE 211, OECD Guideline for Testing of Chemicals; Daphnia magna Reproduction Test. Available online: http://www.oecd-ilibrary.org/environment/test-no-211-daphnia-magnareproduction-test_9789264185203-en (accessed on 28 May 2015).

117. McLachlan, J.A. Environmental signaling: What embryos and evolution teach us about endocrine disrupting chemicals. Endocr. Rev. 2001, 22, 319-341.

118. Iguchi, T.; Sumi, M.; Tanabe, S. Endocrine disruptor issues in Japan. Congen. Anorm. 2002, 42, $106-119$.

119. Comber, M.H.I.; Williams, T.D.; Stewart, K.M. The effects of nonylphenol on Daphnia magna. Water Res. 1993, 27, 273-276.

120. Tatarazako, N.; Takao, Y.; Kishi, K.; Onikura, N.; Arizono, K.; Iguchi, T. Styrene dimers and trimers affect reproduction of daphnid (Ceriodaphnia dubia). Chemosphere 2002, 48, 597-601.

121. Tatarazako, N.; Oda, S.; Watanabe, H.; Morita, M.; Iguchi, T. Juvenile hormone agonists affect the occurrence of male Daphnia. Chemosphere 2003, 53, 827-833.

122. Schultz, T.W.; Freeman, S.R.; Dumont, J.N. Uptake, depuration, and distribution of selenium in Daphnia and its effects on survival and ultrastructure. Arch. Environ. Contam. Toxicol. 1980, 9 , 23-40.

123. Cooper, N.L.; Bidwell, J.R.; Kumar, A. Toxicity of copper, lead, and zinc mixtures to Ceriodaphniadubia and Daphnia carinata. Ecotoxicol. Environ. Saf. 2009, 72, 1523-1528.

124. Jurado, E.; Fernández-Serrano, M.; Núñez Olea, J.; Lechuga, M.; Jiménez, J.L.; Ríos, F. Acute toxicity of alkylpolyglucosides to Vibrio fischeri, Daphnia magna and microalgae: A comparative study. Bull. Environ. Contam. Toxicol. 2012, 88, 290-295.

125. Collard, H.J.; Ji, K.; Lee, S.; Liu, X.; Kang, S.; Kho, Y.; Ahn, B.; Ryu, J.; Lee, J.; Choi, K. Toxicity and endocrine disruption in zebrafish (Danio rerio) and two freshwater invertebrates (Daphnia magna and Moina macrocopa) after chronic exposure to mefenamic acid. Ecotoxicol. Environ. Saf. 2013, 94, 80-86.

126. Zhao, C.M.; Wang, W.X. Importance of surface coatings and soluble silver in silver nanoparticles toxicity to Daphnia magna. Nanotoxicology 2012, 6, 361-370.

127. Newton, K.M.; Puppala, H.L.; Kitchens, C.L.; Colvin, V.L.; Klaine, S.J. Silver nanoparticle toxicity to Daphnia magna is a function of dissolved silver concentration. Environ. Toxicol. Chem. 2013, 32, 2356-2364.

128. Blinova, I.; Niskanen, J.; Kajankari, P.; Kanarbik, L.; Käkinen, A.; Tenhu, H.; Penttinen, O.P.; Kahru, A. Toxicity of two types of silver nanoparticles to aquatic crustaceans Daphnia magna and Thamnocephalus platyurus. Environ. Sci. Pollut. Res. Int. 2013, 20, 3456-3463.

129. Jo, H.J.; Choi, J.W.; Lee, S.H.; Hong, S.W. Acute toxicity of Ag and CuO nanoparticle suspensions against Daphnia magna: The importance of their dissolved fraction varying with preparation methods. J. Hazard. Mater. 2012, 227-228, 301-308. 
130. Fouqueray, M.; Dufils, B.; Vollat, B.; Chaurand, P.; Botta, C.; Abacci, K.; Labille, J.; Rose, J.; Garric, J. Effects of aged $\mathrm{TiO}_{2}$ nanomaterial from sunscreen on Daphnia magna exposed by dietary route. Environ. Pollut. 2012, 163, 55-61.

131. Heinlaan, M.; Ivask, A.; Blinova, I.; Dubourguier, H.C.; Kahru, A. Toxicity of nanosized and bulk $\mathrm{ZnO}, \mathrm{CuO}$ and $\mathrm{TiO}_{2}$ to bacteria Vibrio fischeri and crustaceans Daphnia magna and Thamnocephalus platyurus. Chemosphere 2008, 71, 1308-1316.

132. Lubbock, J. An account of the two methods of reproduction in Daphnia, and of the structure of the ephippium. Philos. Trans. R. Soc. Lond. 1857, 147, 79-100.

133. Zaffagnini, F.; Peters, R.H.; de Bernardi, R. Reproduction in Daphnia. Mem. Ist. Ital. Idrobiol. 1987, 45, 245-284.

134. Kleiven, O.T.; Larsson, P.; Oikos, A.H. Sexual reproduction in Daphnia magna requires three stimuli. OIKOS 1992, 65, 197-206.

135. Thompson, J.D. Phenotypic plasticity as a component of evolutionary change. Trends Evol. Ecol. 1991, 6, 246-249.

136. Depledge, M.H. Genotypic toxicity: Implications for individuals and populations. Environ. Health Perspect. 1994, 102, 101-104.

137. Shugart, L.R.; Theodorakis, C. Genetic ecotoxicology: The genotypic diversity approach. Comp. Biochem. Physiol. 1996, 113, 273-276.

138. Moens, L.N.; van der Ven, K.; van Remortel, P.; del-Favero, J.; de Coen, W.M. Expression profiling of endocrine-disrupting compounds using a customized Cyprinus carpio cDNA microarray. Toxicol. Sci. 2006, 93, 298-310.

139. Moens, L.N.; Smolders, R.; van der Ven, K.; van Remortel, P.; del-Favero, J.; de Coen, W.M. Effluent impact assessment using microarray-based analysis in common carp: A systems toxicology approach. Chemosphere 2007, 67, 2293-2304.

140. Koedrith, P.; Boonprasert, R.; Kwon, J.Y.; Kim, I.S.; Seo, Y.R. Recent toxicological investigations of metal or metal oxide nanoparticles in mammalian models in vitro and in vivo: DNA damaging potential, and relevant physicochemical characteristics. Mol. Cell. Toxicol. 2014, 10, 107-126.

(C) 2015 by the authors; licensee MDPI, Basel, Switzerland. This article is an open access article distributed under the terms and conditions of the Creative Commons Attribution license (http://creativecommons.org/licenses/by/4.0/). 